\title{
Preliminary Assessment of Utilization of Al-Jaif Scoria (NW Sana'a, Yemen) for Cement Production
}

\author{
Ibrahim A. Al-Akhaly ${ }^{1 *}$, Ahmed M. Al-Anweh ${ }^{2}$ and Mohammed I. El-Anbaawy ${ }^{3}$
}

\begin{abstract}
${ }^{1}$ Department of Earth and Environmental Science, Faculty of Science, Sana'a University; ${ }^{2}$ Amran Cement Plant, Amran, Yemen; ${ }^{3}$ Department of Geology, Faculty of Science, Cairo University. ${ }^{*}$ Email: Ibnalakhaly@hotmail.com
\end{abstract}

\begin{abstract}
This paper presents the results of investigations on the potential industrial utilization of scoria, collected from Al-Jaif quarry, NW Sana'a, Yemen as a cement additive. Scoria was chosen as a cement additive material due to its availability and low cost from the Sana'a-Amran volcanic field in Yemen. The chemical composition of scoria was determined by X-ray fluorescence (XRF). The studied scoria is mainly composed of volcanic glass with a few zeolites (e.g. clinoptilolite) as revealed from petrographic investigation and X-ray diffraction (XRD). The scoria was added to the clinker in the range of 2, 4, 6, 8, 10 and $12 \%$ by weight. The fineness, surface area, water demand, setting time and compressive strength were conducted on scoria blended cement. According to experimental results, the high volcanic glass allows the addition of up to $12 \%$ scoria to the clinker to maintain a good potential of manufacturing blended cement. The results satisfy the European Standard EN requirements and confirm the viability of using scoria as a cement additive.
\end{abstract}

Keywords: Scoria; Pozzolan; Cement; Al-Jaif; Sana’a; Yemen.

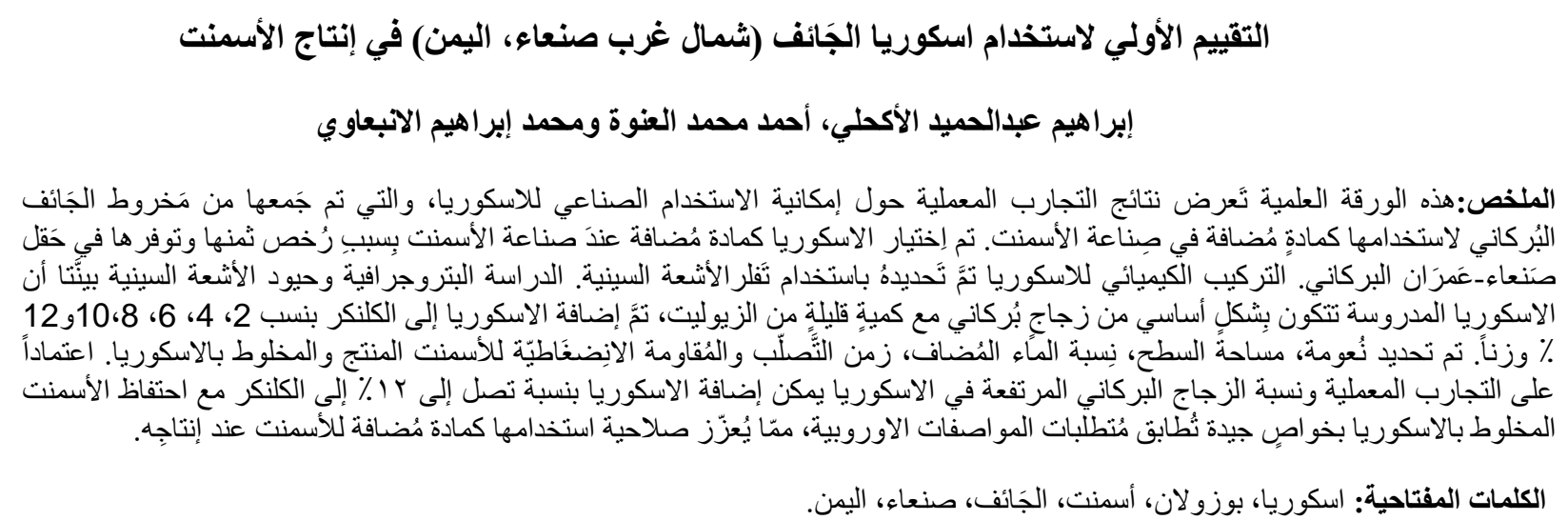

\section{Introduction}

$\mathbf{T}$ he cement industry utilizes natural pozzolans (e.g. scoria) as substitutes for Portland cement (PC) due to their environmental, economic and chemical advantages [1-4]. In this respect pozzolans lower costs and $\mathrm{CO}_{2}$ emissions, and increase chemical resistance of cementacious materials through reduction of the alkali aggregate reaction. The manufacture of one ton of PC clinker consumes about 4 GJ of energy, and releases nearly one ton of $\mathrm{CO}_{2}$ to the atmosphere [5]. World PC clinker production is responsible for about $7 \%$ of the total $\mathrm{CO}_{2}$ emissions [6-8]. For this reason, particular attention has recently been given to the exploitation of scoria in many countries, including Turkey $[9,10]$, Syria [11,12] and Yemen [13,14].

Scoria can be utilized in several industrial applications including the manufacturing of lightweight concrete, as a source of pozzolan to manufacture Portland-pozzolan cement additives, as a heat insulating material, in low cost fillers in paint, filter materials and absorbents, in architectural applications [15], for producing geopolymer mortar [16-18] and as a sand in PC mortar [19]. Scoria is abundant in various parts of the world including Turkey [9,10], Syria [11,12], Saudi Arabia [15,21,22] and Cameroon [16,17,19].

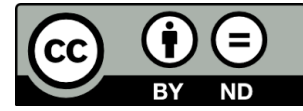


Scoria is also abundant in Yemen [13,14,20], where more than 9,000 $\mathrm{km}^{2}$ of the country is covered with Quaternary volcanic rocks [23] (Figure 1). Scoria is locally used in Yemen in road construction as a sub-base material and there are several quarries operating on scoria deposits in NW Sana'a where the Sana'a-Amran volcanic field covers a total area of some $1200 \mathrm{~km}^{2}$. Whilst scoria has been used in industry worldwide for a long time, it has only had importance in Yemeni industry for the last 6 years. However, Yemen has an important potential reserve of 613 million $\mathrm{m}^{3}$ [24] and about 500,000 metric tons are exploited annually [25].

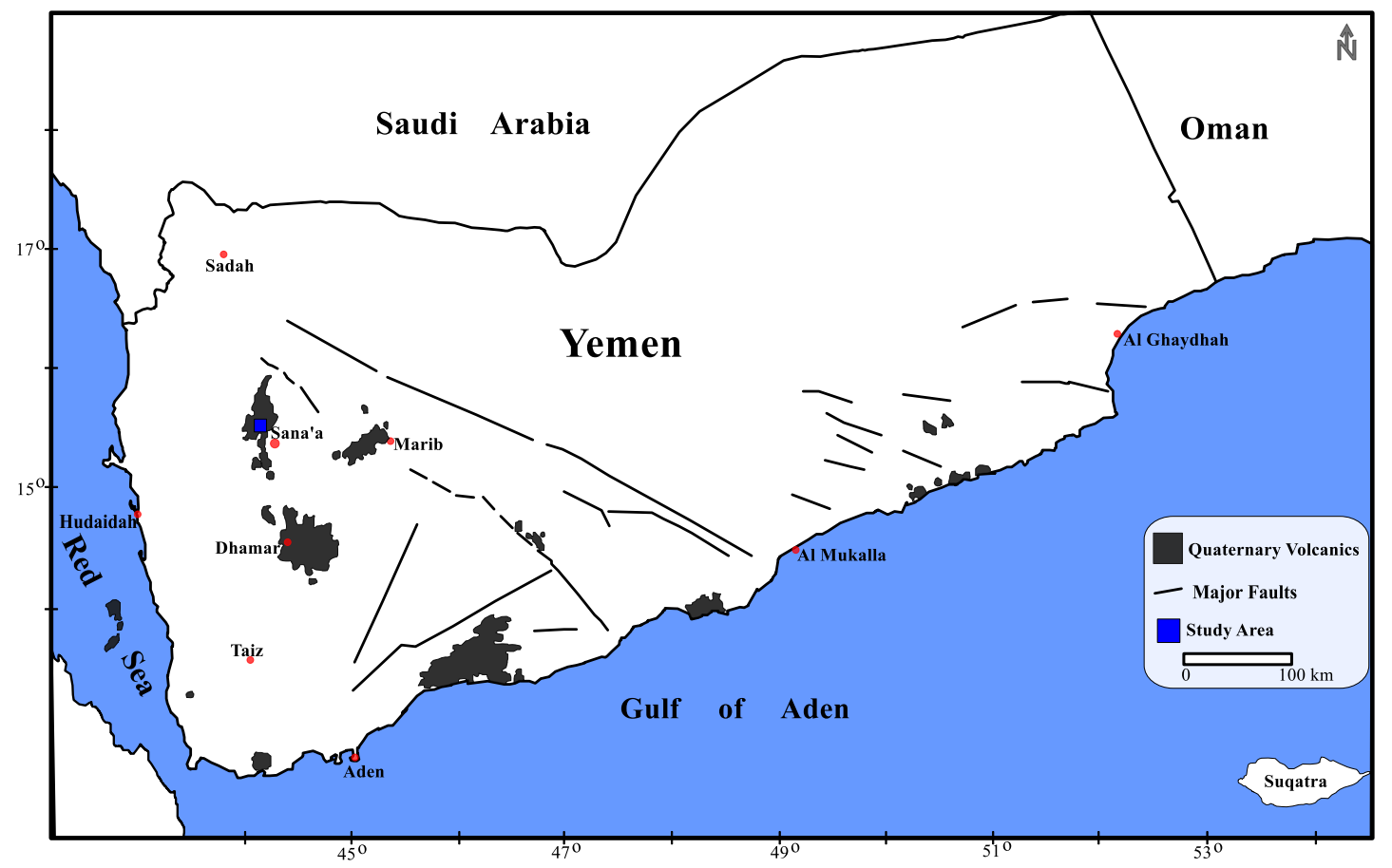

Figure 1. Quaternary volcanic rocks in Yemen [24].

The cement produced in Yemen is almost entirely of PC, although an addition of up to 5\% natural pozzolan is frequently used in most local cement plants.

Previous work has shown the possibility of using scoria in the production of blended cements in Yemen [13]. The aim of the current research is to determine the potential industrial use of scoria from Al-Jaif (NW Sana'a, Yemen) as a cement additive material. The use of scoria as a construction material would provide both low cost cement and also a cleaner environment. This study is important not only for Yemen but also for other countries of similar geological setting.

\section{Materials and methods}

\subsection{Sample preparation}

More than $500 \mathrm{~kg}$ of bulk sample was collected from scoria pyroclastic deposits in the Al-Jaif volcanic cone, about $24 \mathrm{~km} \mathrm{NW}$ of Sana'a, Yemen (Figure 2). Three sub-samples were selected from the bulk sample to represent its apparent lithological varieties. These sub-samples were prepared for thin section investigation. Cutting and polishing processes were performed using an oil system. Glue that hardens under UV light was used. To reduce the amount of sample, sampling was performed using the cone and quartering method and riffles, since sampling must have mineralogical, physical and chemical homogeneity. The sample was crushed and ground using a laboratory dodge jaw crusher, rod mill and ball mill to reduce their size to sieve No. $200(74 \mu \mathrm{m})$ for mineralogical and chemical analyses, which were conducted in Amran Cement Plant (ACP) (Amran/Yemen).

\subsection{Chemical and mineral analysis}

Chemical analysis of five samples of scoria was carried out of by unit model ARL 9800 XP SIM-SEQ XRF of Quality Laboratory of ACP. This XRF device unit is manufactured by Thermo Electron Corporation and uses Rhtube and UniQuant program. The preparation of powder pellets for analysis included crushing the samples using the Jaw Crusher, then grinding them to fine powder using the Disk Vibration Mill. In this stage of sample preparation, about 6-7 $\mathrm{ml}$ of hexane $\left(\mathrm{C}_{6} \mathrm{H}_{14}\right)$ were added to the crushed sample in order to decrease the temperature during the grinding.

To investigate petrographical characteristics of the sample, thin sections of three representative samples were prepared and determined using the LEICA Polarizing Microscope. These thin sections were carried out in the 
Geology Department, Faculty of Science, Cairo University, Cairo, Egypt. These investigations were supported by bulk mineralogical study using a Philips XRD equipment model PW/1710 with Monochromator Cu-radiation $(\lambda$ $=1.542 \mathrm{~A}^{\circ}$ ) at $40 \mathrm{~K} . \mathrm{V} ., 35 \mathrm{~m} . \mathrm{A}$. and a scanning speed of $0.02^{\circ} / \mathrm{sec}$. The reflection peaks between $2 \theta=2^{\circ}$ and $60^{\circ}$, corresponding spacing (d $\AA$ ) and relative intensities (peak areas) were obtained. The diffraction charts and relative intensities obtained were compared with ICDD files that were carried out by the Egyptian Mineral Resources Authority (EMRA), Cairo, Egypt.

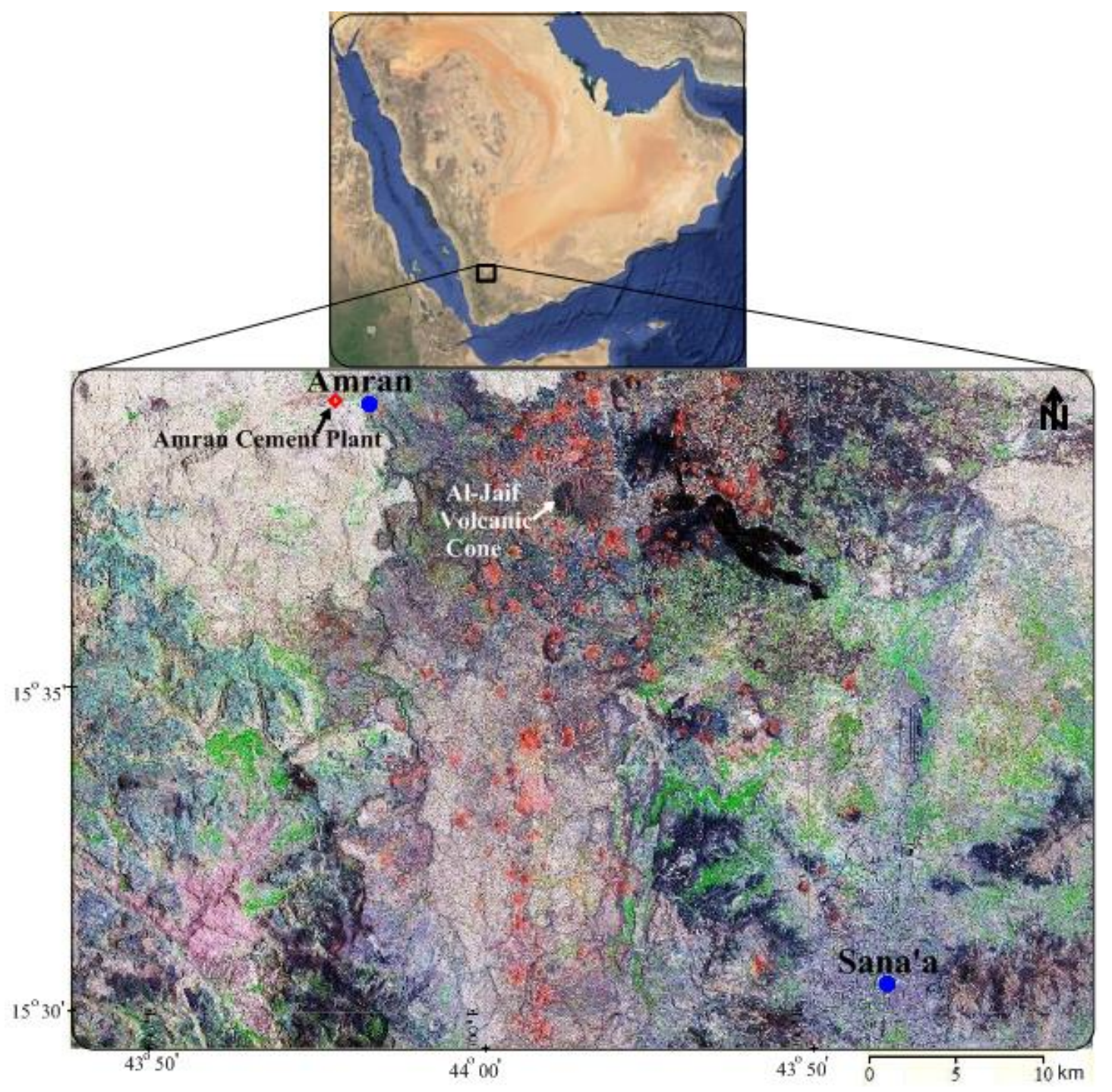

Figure 2. Satellite image showing the location of the studied scoria field and the Amran Cement Plant [26].

\subsection{Test specimen Preparation}

The clinker used for producing all types of cement ( $\mathrm{PC}$ and scoria blended cement) was obtained from ACP (Amran/Yemen) (Figure 2). The clinker, scoria and gypsum were mixed to produce cement. A reference cement (pure PC) was produced by mixing PC clinker, $96 \%$, and gypsum, $4 \%$ by weight. This mixture was then ground for 40 minutes in a laboratory-type ball mill. Scoria blended cement samples were obtained by replacing 2, 4, 6, 8, 10 and $12 \%$ (by weight of clinker) of the PC clinker by scoria and mixing and inter-grinding. The gypsum content was kept constant in all cements at 4\%. Before the grinding operation, PC clinker, scoria and gypsum were crushed and sieved through a $9.5 \mathrm{~mm}$ sieve to maintain uniformity between the specimens through using the same feed size. PC clinker, scoria and gypsum were ground to fine powder using a ring crusher to obtain a Blaine fineness of about $3200 \mathrm{~cm}^{2} / \mathrm{gm}$. The gypsum was dried at $40^{\circ} \mathrm{C}$ prior to crushing whereas the scoria was dried at $110^{\circ} \mathrm{C}$.

\subsection{Cement Tests}

Analyses of the chemical composition of the PC (reference specimen) and scoria blended cements were performed by the XRF. Fineness analyses were performed in accordance with EN 196-6 [27]. The fineness of the blended cement samples was determined by measuring the Blaine fineness and amount of material retained on 45 $\mu \mathrm{m}$ and $90 \mu \mathrm{m}$ sieves after vacuum sieving. The following tests were carried out on the PC and blended materials: 
fineness, specific surface area by Blaine instrument, normal consistency, setting time and compressive strength. The amount of water necessary for the cements to have normal consistency was determined according to EN 196-3 [28]. Pastes having normal consistency were then used to determine the setting time by conducting tests as described in this standard. Preparation of cement mortar mixtures was completed according to EN 196-1 [29]. In these tests, 450 $\pm 2 \mathrm{gm}$ of cement and $1350 \pm 5 \mathrm{gm}$ of standard sand were used. Scoria blended cement mortars were prepared with $225 \mathrm{~cm}^{3}$ of water so that the water content of the scoria blended cement mortars were adjusted to have a w/c ratio of 0.5 as stated in the standards. The prepared mortars were poured into cubic shaped three-part mortar molds $7.06 \times 7.06 \times 7.06 \mathrm{~cm}^{3}$ (surface area $50 \mathrm{~cm}^{2}$ ). The mortar specimens of all cements used in the experiments were prepared in a laboratory environment at a room temperature of $20 \pm 2{ }^{\circ} \mathrm{C}$ and $80 \pm 4 \%$ relative humidity. After being kept in a wet cabinet for 24 hours, the mortar specimens were demulded and kept in water until they were tested. Compressive strength tests were performed by an automated strength testing machine in accordance with EN 196-1 [29]. The compressive strength of the cubes was determined after 3, 7 and 28 days curing. Three cube specimens were tested for each day for each type of cement. The reported values represent the average of three readings.

\section{Results and discussion}

\subsection{Scoria composition}

Al-Jaif scoria is one of the natural pozzolan volcanic cones in Yemen that formed during Quaternary explosive eruptions. It has a highly porous structure which was formed by dissolved gases precipitated during cooling as the lava hurtled through the air. Therefore, scoria consists of pyroclastic ejects, of irregular morphology, and has the basic composition of basalt. It is formed of vesicular fine to coarse fragments, reddish or black in color and light in weight.

Petrographic investigation shows that the scoria is mainly composed of volcanic glass with phenocrystals of olivine in the matrix and has hyalopilitic-porphyritic and vitrophyric-porphyritic textures with vesicles in the matrix (Figure 3a). The vesicles are filled with secondary minerals (e.g. chlorite) (Figure 3b). Olivine is easily distinguished by color tone and Y-cracks (Figure 3c).
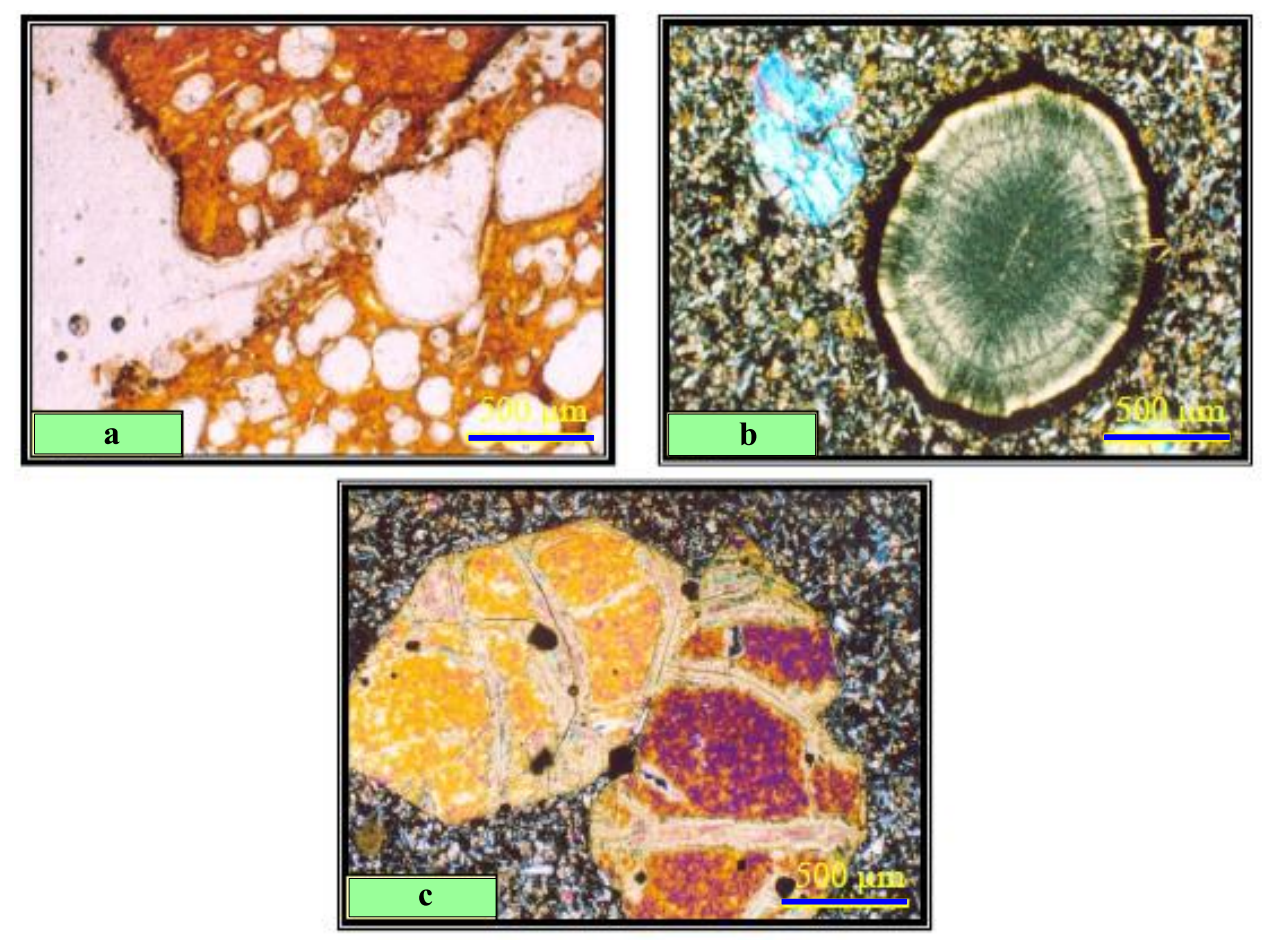

Figure 3. Microphotographs of scoria sub-samples: (a) Connected and isolated vesicles in reddish brown glassy groundmass, (b) The vesicles filled with chlorite, (c) Cracked phenocrysts of altered olivine to iddengzite.

The results of chemical analysis of the scoria sub-sample are given in Table 1. Chemical analysis indicates that $\mathrm{SiO}_{2}, \mathrm{Al}_{2} \mathrm{O}_{3}, \mathrm{Fe}_{2} \mathrm{O}_{3}, \mathrm{CaO}$ and $\mathrm{MgO}$ constitute its major contents. According to the XRF results, scoria shows basic composition due to the relatively low $\mathrm{SiO}_{2}$ and high $\mathrm{Fe}_{2} \mathrm{O}_{3}$ contents.

The chemical composition of the scoria was compared with that of ASTM Type I PC (Table 1). Chemical analysis indicates that scoria is mainly composed of $\mathrm{SiO}_{2}(46.55 \%)$; while the main oxide component of $\mathrm{PC}$ is $\mathrm{CaO}$ 
(60-67\%). However, scoria also has $\mathrm{CaO}(9.34 \%), \mathrm{Al}_{2} \mathrm{O}_{3}(16.68 \%)$ and $\mathrm{Fe}_{2} \mathrm{O}_{3}(38.56 \%)$. The content of $\mathrm{Na}_{2} \mathrm{O}$ and $\mathrm{K}_{2} \mathrm{O}$ known as 'alkalis' was found to be higher in scoria $(3.55 \%)$ than in $\mathrm{PC}(\leq 1 \%)$.

The XRD pattern of scoria is given in Figure 4. As stated before, scoria is an amorphous volcanic rock. XRD data (Figure 4) indicates that, scoria consists mainly of glassy volcanic materials (of amorphous structure), with some crystalline mineral phases, e.g. labradorite, bytownite, pigeonite, augite, forsterite, magnetite, zeolite (clinoptilolite), calcite and caladonite, and with traces of clay minerals (mainly kaolinite and chlorite).

Table 1. Chemical composition of the studied bulk scoria sample and ASTM Type I PC.

\begin{tabular}{ccc}
\hline Oxides & $\begin{array}{c}\text { Scoria } \\
\text { (mass, \%) }\end{array}$ & $\begin{array}{c}\text { ASTM Type I PC [30] } \\
\text { (mass, \%) }\end{array}$ \\
\hline $\mathrm{SiO}_{2}$ & 46.55 & $17-25$ \\
$\mathrm{Al}_{2} \mathrm{O}_{3}$ & 16.68 & $3.0-8.0$ \\
$\mathrm{Fe}_{2} \mathrm{O}_{3}$ & 12.54 & $0.5-6.0$ \\
$\mathrm{CaO}$ & 9.34 & $60-67$ \\
$\mathrm{MgO}$ & 7.82 & $0.5-4.0$ \\
$\mathrm{~K} 2 \mathrm{O}$ & 0.86 & $0.5-1.3$ \\
$\mathrm{Na}_{2} \mathrm{O}$ & 2.69 & $0.5-1.3$ \\
$\mathrm{SO}_{3}$ & 0.05 & $1.0-3.0$ \\
$\mathrm{P}_{2} \mathrm{O}_{3}$ & 0.36 & - \\
$\mathrm{TiO}_{2}$ & 2.09 & - \\
$\mathrm{LOI}^{\mathrm{Total}}$ & 0.67 & 1.22 \\
\hline
\end{tabular}

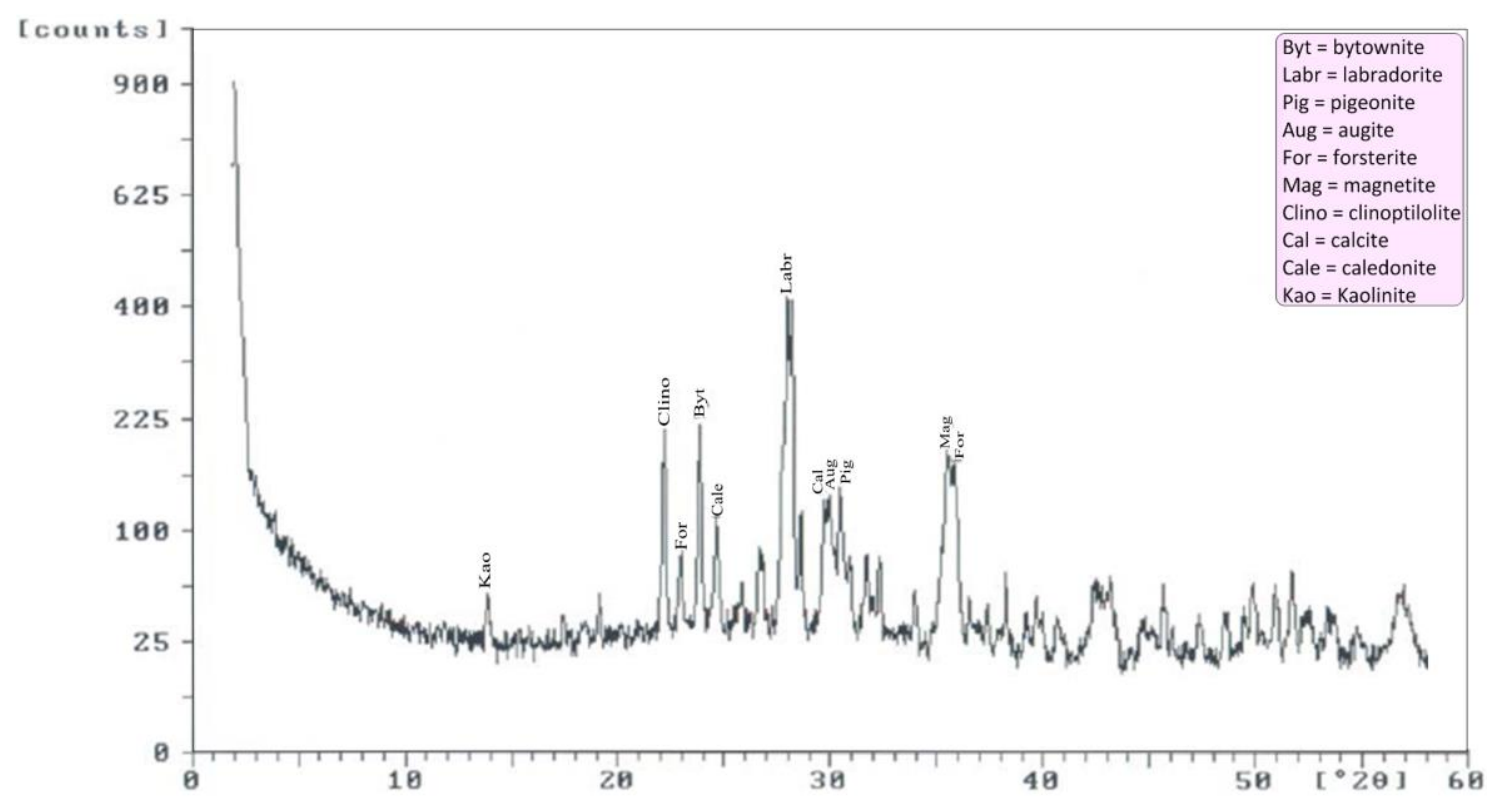

Figure 4. X-ray diffraction chart of the scoria bulk sample.

Scoria can be considered a good component for the cement industry if it contains volcanic glass and high amounts of zeolite minerals [30]. The thin section studies show that scoria is mainly composed of volcanic glass, while the XRD analysis indicates the presence of a few zeolites mainly in the form of clinoptilolite mineral, establishing that the Al-Jaif scoria is a good additive for the cement industry.

\subsection{Cement properties}

Chemical analyses of the control specimen and scoria blended cements are given in Table 2 . The chemical composition of the PC indicates that the $\mathrm{CaO} / \mathrm{SiO}_{2}$ ratio is greater than 2 and the percent of $\mathrm{MgO}$ content is smaller than 5\%. These values satisfy the main composition requirements imposed by the EN 197-1 [32]. Due to the scoria's chemical composition, $\mathrm{SiO}_{2}, \mathrm{Al}_{2} \mathrm{O}_{3}, \mathrm{Fe}_{2} \mathrm{O}_{3}$ and $\mathrm{MgO}$ contents increase and $\mathrm{CaO}$ content decreases with increasing the scoria content ratio in the cement mixture (Figure 5). 
Physical and mechanical properties of PC and scoria blended cements are given in Table 3. They have nearly the same water demand ratio. This was evidenced by the results of water demand of the investigated mortar mixes. Therefore the scoria's effect on the compressive strength of mortars could be considered marginal. A literature survey shows that the chemical composition, porosity and specific surface area of cement mixtures affect water demand [34].

The setting times of the PC and scoria blended cement mortars including 2, 4, 6, 8, 10 and $12 \%$ scoria content ratio were all close.

Table 2. Chemical composition of the control (PC) and the scoria blended cements.

\begin{tabular}{|c|c|c|c|c|c|c|c|c|c|}
\hline \multirow{2}{*}{ Oxides } & \multirow{2}{*}{$\begin{array}{l}\mathbf{P C} \\
(\%)\end{array}$} & \multicolumn{6}{|c|}{ Scoria $(\%)$} & \multirow{2}{*}{$\begin{array}{l}\text { ASTM Type } \\
\text { I PC [30] }\end{array}$} & \multirow{2}{*}{$\begin{array}{c}\text { Standard } \\
\text { After Ghosh } \\
{[33]}\end{array}$} \\
\hline & & 2 & 4 & 6 & 8 & 10 & 12 & & \\
\hline $\mathrm{SiO}_{2}$ & 20.32 & 20.89 & 21.15 & 21.74 & 22.39 & 22.75 & 23.31 & $17-25$ & $20 \pm 6$ \\
\hline $\mathrm{Al}_{2} \mathrm{O}_{3}$ & 5.58 & 5.86 & 6.06 & 6.37 & 6.61 & 6.82 & 7.12 & $3.0-8.0$ & $6 \pm 2$ \\
\hline $\mathrm{Fe}_{2} \mathrm{O}_{3}$ & 2.98 & 3.08 & 3.33 & 3.41 & 3.67 & 3.99 & 3.96 & $0.5-6.0$ & $3 \pm 2$ \\
\hline $\mathrm{CaO}$ & 61.78 & 60.67 & 59.5 & 58.38 & 57.46 & 56.25 & 55.13 & $60-67$ & $62 \pm 5$ \\
\hline $\mathrm{MgO}$ & 1.71 & 1.77 & 1.80 & 1.86 & 1.91 & 1.96 & 2.01 & $0.5-4.0$ & $3.5 \pm 1.5$ \\
\hline $\mathrm{SO}_{3}$ & 2.26 & 2.42 & 2.15 & 2.22 & 2.19 & 2.10 & 2.09 & $1.0-3.0$ & $1.5 \pm 1.2$ \\
\hline $\mathrm{TiO}_{2}$ & 0.31 & 0.36 & 0.41 & 0.45 & 0.50 & 0.54 & 0.60 & minor & minor \\
\hline $\mathrm{Na}_{2} \mathrm{O}$ & 0.07 & 0.15 & 0.22 & 0.31 & 0.38 & 0.46 & 0.55 & $0.5-1.3$ & $0.7 \pm 0.3$ \\
\hline $\mathrm{P}_{2} \mathrm{O}_{5}$ & 0.11 & 0.11 & 0.13 & 0.15 & 0.17 & 0.19 & 0.21 & minor & minor \\
\hline $\mathrm{MnO}$ & 0.07 & 0.08 & 0.09 & 0.09 & 0.10 & 0.11 & 0.12 & minor & minor \\
\hline $\mathrm{K}_{2} \mathrm{O}$ & 1.03 & 1.03 & 1.01 & 1.01 & 1.00 & 1.00 & 0.98 & $0.5-1.3$ & $0.7 \pm 0.3$ \\
\hline
\end{tabular}

Table 3. Physical and mechanical properties of the control and the blended cements.

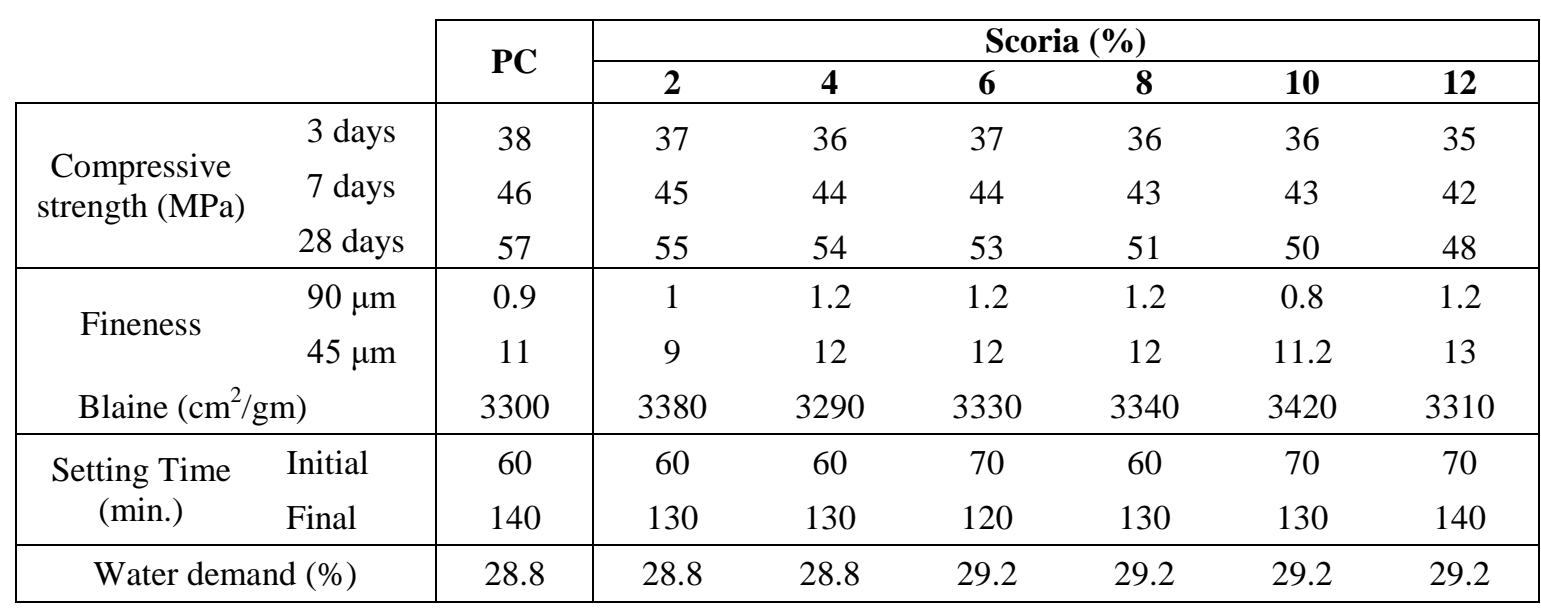

The scoria blended cement mortars to be used for compressive strength testing were prepared to have a w/c of 0.5 as stated in EN 196-1 [29]. Table 3 shows the compressive strength values after 3, 7 and 28 days curing. The results of compressive strength development for all mortar mixes containing varying amounts of scoria are given in Figures 6 and 7. As expected,all mortars show an increase in strength with curing time. Mortar specimens containing PC have higher compressive strengths at any curing time compared to scoria blended cement mortars. Also, it is seen that the compressive strength of scoria blended cement mortars decreases as the scoria content increases for all curing times. In EN 197-1 [32], early strength (3 days) values should be greater than $10 \mathrm{MPa}$ and standard strength (28 days) values should be between $42.5 \mathrm{MPa}$ and $62.5 \mathrm{MPa}$. A literature survey shows that the compressive strength of a mortar is decreased by scoria content, due to the reduction of clinker content in the cement mixture [10-12]. However, according to comparison of the obtained results with the EN 197-1 [32], the strength requirements were satisfied by the scoria blended cements up to $12 \%$ content. 

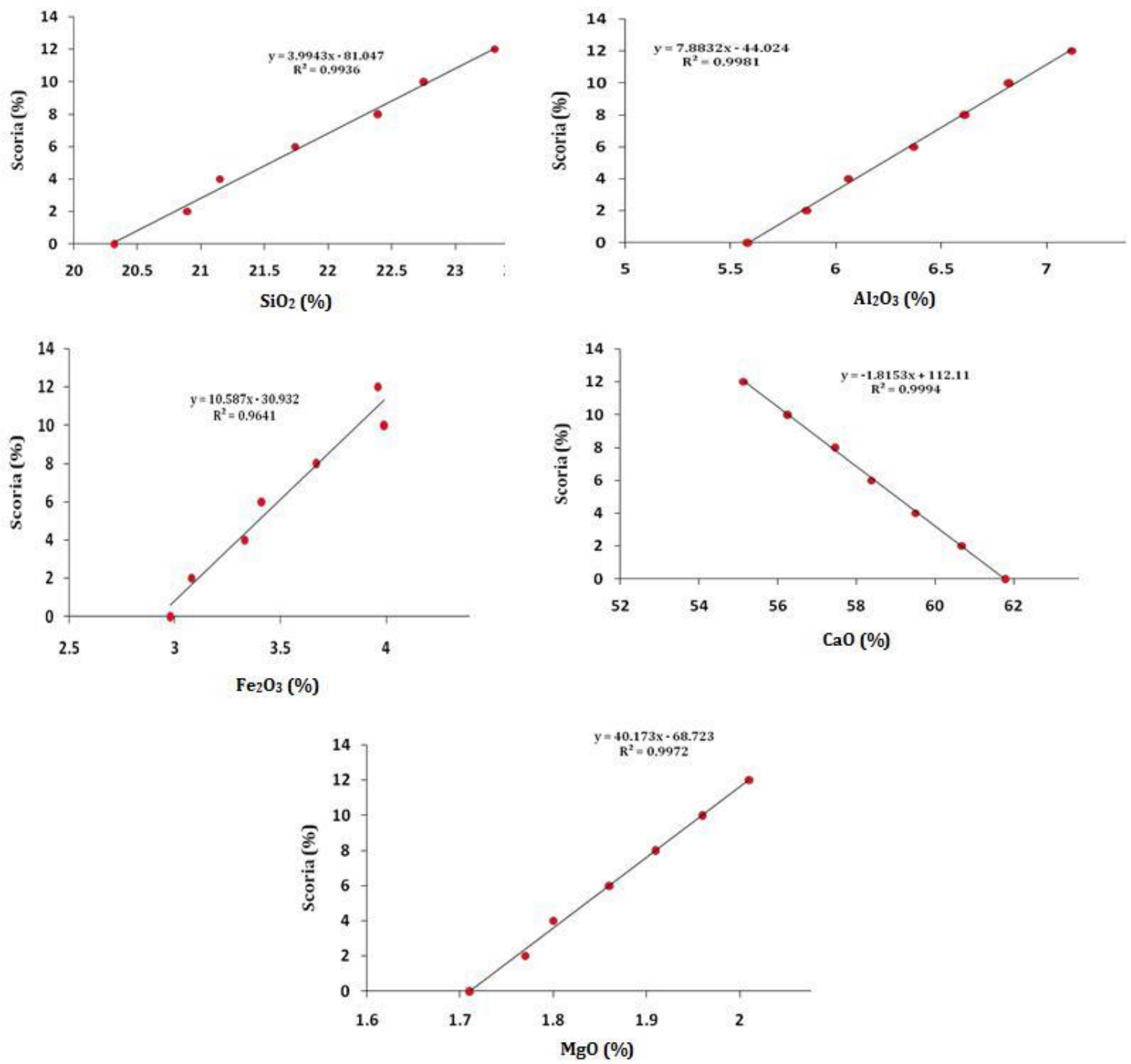

Figure 5. Relationship between major oxides and the scoria content in cements.

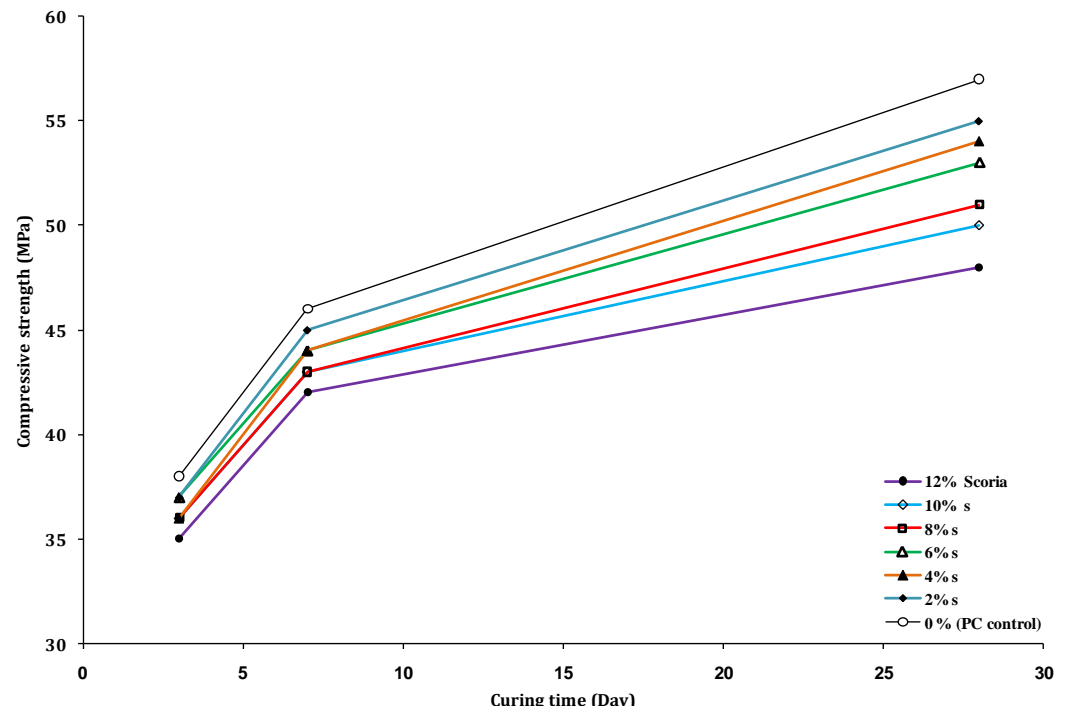

Figure 6. Correlation between compressive strength of the PC and the scoria blended cement at different curing times. 
IBRAHIM A. AL-AKHALY ET AL

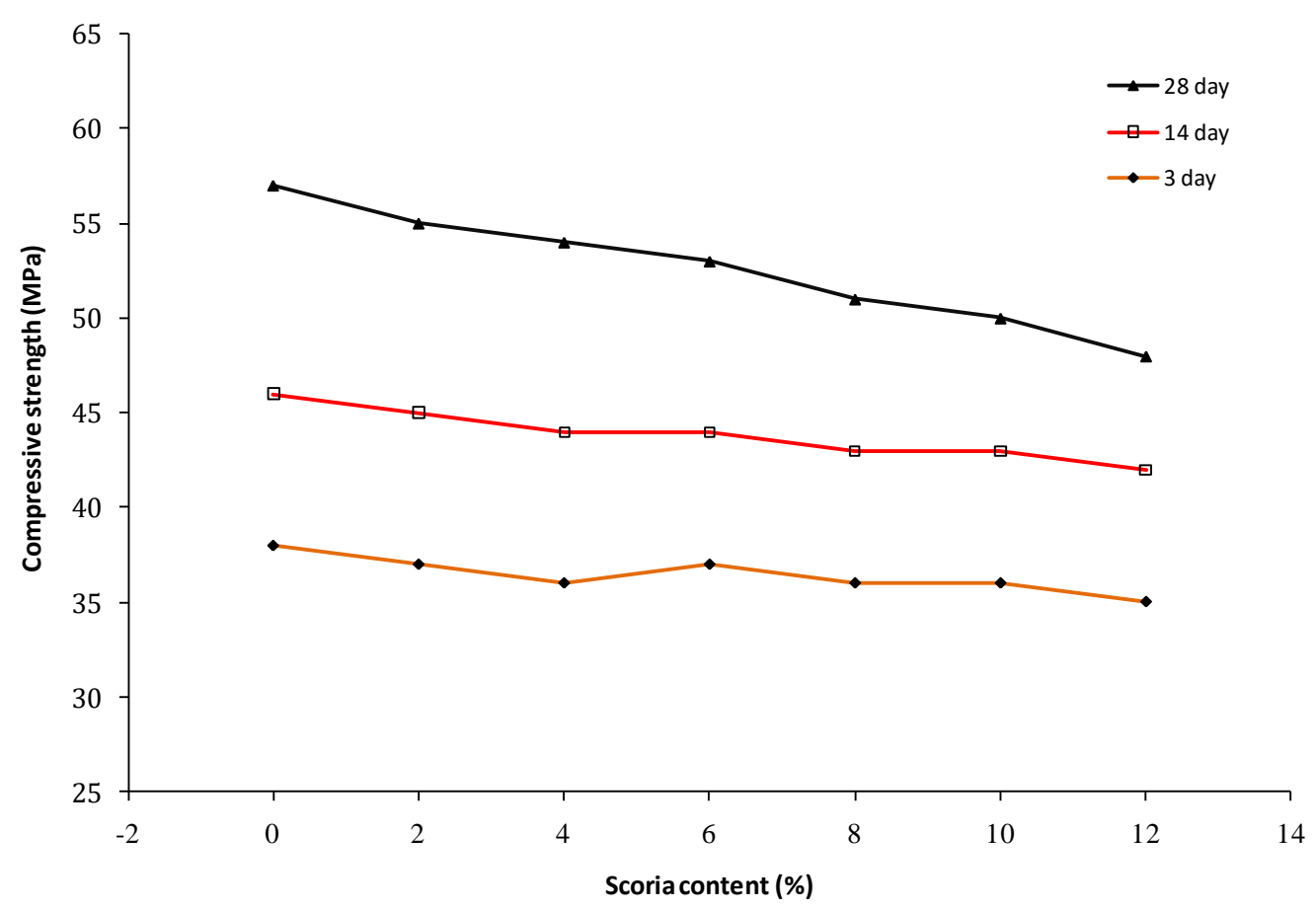

Figure 7. Effect of the scoria content on compressive strength at different curing times.

\section{Conclusion}

This paper describes the potential use of scoria from Al-Jaif (NW Sana'a, Yemen) as an additive material to manufacture blended cement. The following conclusions were obtained: The studied scoria is mainly composed of amorphous silica (volcanic glass) and there are phenocrysts of olivine, plagioclase, pyroxene and a few of zeolite (clinoptilolite). It has a mainly hyalopilitic-porphyritic texture. Accordingly, it can be considered as a good additive for the cement industry. The scoria has as its major chemical components $\mathrm{SiO}_{2}, \mathrm{Al}_{2} \mathrm{O}_{3}$ and $\mathrm{Fe}_{2} \mathrm{O}_{3}$, conforming to the chemical requirements of the ASTM and EN standards. The experimental results presented in this study show that the physical characteristics of the cement containing scoria are in conformity with the standard requirements. The scoria possesses sufficient pozzolanic characteristics to be used as an additive during cement production, since it satisfies the standard requirements. Finally, according to the results obtained, it is suggested that Al-Jaif scoria can be used up to $12 \%$ as a partial substitute for PC in production of blended cement. This addition ratio could provide economic and environmental benefits due to reduced clinker consumption and lowered $\mathrm{CO}_{2}$ emissions from cement production.

\section{References}

1. Vuk, T., Gabrovsek, R., Kaucic, V. The influence of mineral admixtures on sulfate resistance of limestone cement pastes aged in cold $\mathrm{MgSO}_{4}$ solution. Cement Concrete Composition, 2002, 32, 943-8.

2. Saraswathy, V., Muralidharan, S., Thangavel, K., and Srinivasan, S. Influence of activated fly ash on corrosion-resistance and strength of concrete, Cement Concrete Research, 2003, 25, 673-80.

3. Binici, H. and Aksogan, O. Sulfate resistance of plain and blended cement, Cement Concrete Composition, 2006, 28, 39-46.

4. Yilmaz, B. Effects of Molecular and Electrokinetic Properties of Pozzolans on Hydration. ACI Materials Journal, 2009, 106(2), 128-137.

5. Mehta, P.K. and Monteiro, P.J. Concrete: Microstructure, properties, and Materials. 3rd Edition, McGrawHill, 2006.

6. Ghrici, M., Kenai, E. and Meziane, E. Mechanical and Durability Properties of Cement Mortar with Algerian Natural Pozzolan. Journal of Material Science, 2006, 41(21), 6956-6972. doi:10.1007/s10853-006-0227-0

7. Aitcin, P.C. and Mindess, S. Sustainability of concrete, Spon Press, 2011

8. Ramezanianpour, A.A. Cement replacement materials: Properties, durability, sustainability. Springer-Verlag Berlin Heidelberg, 2014

9. Hossain, K.M. Volcanic ash and pumice as cement additives: pozzolanic, alkali-silica reaction and autoclave expansion characteristics. Cement and Concrete Research, 2005, 35, 1141-1144.

10. Ozvan, A., Tapan, M., Erik, O., Efe, T. and Depcia, T. Compressive Strength of Scoria Added Portland Cement Concretes. Gazi University Journal of Science, 2012, 25(3), 769-775 


\section{PRELIMINARY ASSESSMENT OF UTILIZATION}

11. Al-Swaidani, A.M., Aliyan, S.D. and Adarnaly, N. Mechanical strength development of mortars containing volcanic scoria-based binders with different fineness. Engineering Science and Technology, an International Journal, 2016, 19, 970-979.

12. Al-Swaidani, A.M. Production of more durable and sustainable concretes using volcanic scoria as cement replacement, Materiales de Construcción, 2017, 67(326)http://dx.doi.org/10.3989/mc.2017.00716

13. Al-Anweh, A.M. Geology and cement industrial applications on Carbonate and clay deposits around Sana'a basin, Republic of Yemen, M.Sc. Thesis, Geology Department, Faculty of Science, Cairo University, Egypt, 2010

14. Al Naaymi, T.A. Assessment of Pumice and Scoria Deposits in Dhamar -Rada' Volcanic Field SW- Yemen, as a Pozzolanic Materials and Lightweight Aggregates. International Journal of Innovative Science, Engineering and Technology, 2015, 2(9).

15. Moufti, M.R., Sabtan A.A., El-Mahdy O.R. and Shehata, W.M. Assessing of industrial utilization of scoria materials in the central HarratRahat, Saudi Arabia. Engineering Geology, 2000, 57, 155-162.

16. Tchakouté, H.K., Kong, S., Djobo, J.N., Tchadjié, L.N. and Njopwouo, D. A comparative study of two methods to produce geopolymer composites from volcanic scoria and the role of structural water contained in the volcanic scoria on its reactivity. Ceramics International, 2015, 41.

17. Lemougna, P.N., MacKenzie, K.J. and Melo, U.F. Synthesis and Thermal Properties of Inorganic Polymers (Geopolymers) for Structural and Refractory Applications from Volcanic Ash. Ceramics International, 2011, 37(8), 3011-3018. doi:10.1016/j.ceramint. 2011.05.002

18. Kamseu, E., Leonelli, C., Perera, D.S., Melo, U.F. and Lemougna, P.N. Investigation of Volcanic Ash-Based Geo- polymers as Potential Building Materials. Ceramics International, 2009, 58(2), 136-140.

19. Tchamdjou, W.H., Grigoletto, S., Michel, F., Courard, L., Abidi, M.L. and Cherradi, T. An investigation on the use of coarse volcanic scoria as sand in Portland cement mortar. Case Studies in Construction Materials, 2017, 7, 191-206.

20. Al-Sabri, A.M. Geology and Economic Potentiality of the Scoria Deposits in Dhamar-Rada Volcanic Field, Yemen, Ph.D. Thesis, Sana'a University, Faculty of Science, Earth and Environmental Science Department. 2009.

21. Sabtan, A.A. and Shehata, W.M. Evaluation of engineering properties of scoria in central HarratRahat, Saudi Arabia. Bulletin of the Engineering Geology and the Environment, 2000, 59, 219-225.

22. Alhozaimy, A., Fares, G., Alawad, O.A. and Al-Negheimish, A. Heat of hydration of concrete containing powdered scoria rock as a natural pozzolanic material. Construction and Building Materials, 2015, 81, 113119

23. Beydoun, Z.R., As-Saruri, M.A., El-Nakhal, H., Al-Ganad, I.N., Baraba, R.S., Nani, A.O., and Al-Aawah, M.H. International Lexicon of Stratigraphy, Republic of Yemen, IUGS and Ministry of Oil and Mineral Resources, Sana'a, Republic of Yemen. 1998, 245p.

24. YGSMRB. Annual Technical Report, Sana'a, Yemen, 2005.

25. USGS. 2014 Minerals Yearbook of Yemen, New York, 2016.

26. www.glcf.umd.edu/data/landsat

27. EN 196-6. Methods of testing cement-Part 6: Determination of fineness, 2002.

28. EN 196-3. Methods of testing cement-Part 3: Determination of setting time and soundness, 2002.

29. EN 196-1, "Methods of testing cement-Part 1: Determination of strength", 2002.

30. ASTM. Standard Specification for Portland Cement, Designation: C 150-07, 2007 www.astm.org.

31. Planungs Engineering Management Report, On investigations of Turkish natural pozzolans as cement admixtures, Ankara, Turkey. 1984

32. EN 197-1. Cement- Part 1: Compositions and conformity criteria for common cements, 2002.

33. Ghosh, S.N. Progress in cement and concrete. Science Technology. Cement Research institute of India. Part 1. 1990, 489p.

34. Lea, F.M. The chemistry of cement and concrete, 3rd Edition. London: Arnold Publishers, London, UK, 1976.

Received 15 October 2017

Accepted 26 February 2018 